general psychiatry as well as for the main readership in primary care. There are usefu accounts of interactive services between general practitioners and specialists, but the text repeatedly warns that some treatments (for example, relapse prevention and injectable drugs) are beyond its scope. The volume offers a convenient introduction for the novice trainee in substance misuse. Further information is required to gain sufficient knowledge for unsupervised practice in the speciality. This is a book for the general psychiatric library, rather than more specialised bookcases.

J. S. Madden Emeritus Consultant Psychiatrist, Department of Psychiatry, Countess of Chester Hospital, Chester $\mathrm{CH} 2$ IUL

\section{Therapeutic Communities. Past, Present and Future}

Edited by Penelope Campling \& Roy Haigh.

London: Jessica Kingsley. 1999.

350 pp. $€ 42.50$ (hb), $€ 15.95$ (pb).

ISBN I-85302-6I4 (hb), I-85302-626-3 (pb)

The therapeutic community movement has been in decline since its heyday after the Second World War. The timing of this book may well be prescient: is a revival of the therapeutic movement taking place? There are a number of books on various aspects of therapeutic communities. This book does not set out to emulate these, but to paint a picture of the diversity and colour within the movement. It is a multi-author book, several of the contributors having written their own authoritative works. It embraces the roots of the therapeutic community movement and goes on to span present practice and possible future development. It is easy to read and there is considerable factual content, not only of the historical development of the therapeutic community movement but the basic concepts of therapeutic communities, their psychoanalytic roots and their application - including the application of group analytic approaches and understanding. Contributors from current therapeutic communities address various clinical issues that arise in the management of their patients who, by and large, have severe personality disorders. These issues include containment, the significance of management of boundaries, the process of attachment and separation, and the management of the conflict between encouraging personal responsibility and the inherent paternalism in the Care Programme Approach.

Chapters describe the application of therapeutic community approaches to various settings, including that of the prison service. The final section of the book responds to contemporary challenges of survival in the market, research and evidence, and issues regarding training in an approach that is fundamentally multidisciplinary. The book is written with passion and conviction and conveys the creative experimentation and radicalism that has characterised the movement. It is salutary to note how few therapeutic communities now exist within the National Health Service.

The content of this book, its tone, the energy that is conveyed and the commitment of the multi-disciplinary teams contrast vividly with what, by many, is seen as the creeping increase in social control and bureaucratisation of the present time. The style and presentation, with an emphasis on the art of therapeutic practice, is a challenge to the current dominance of the scientific clinical approach with the apparent idealisation of a logic, which would appear to be applied even in such complex and challenging cases as the management of severe personality disorders. I recommend this book to all aspiring and practising colleagues, if only to remind themselves of times when the practice of psychiatry could more comfortably embrace notions such as creativity and play, and to consider whether the time has come for their renaissance.

Tony Garelick Consultant Psychiatrist in Psychotherapy, Forest Healthcare Trust \& Tavistock Clinic, 120 Belsize Lane, London NW3 5BA

\section{Psychoanalysis and Mental Handicap}

Edited by Johan De Groef \&

Evelyn Heinmann. London: Free Association Books. 1999. 214 pp. $€ 16.95$ (pb)

ISBN I-85343-43I-0

This book arises from European conferences held in Belgium in 1996 and France in 1997 to exchange ideas on the relations between psychoanalysis and learning disability. The editors and translators for this book have provided a supporting structure for diverse chapters from European psychoanalysts, psychologists, educationalists and an anthropologist to reflect on their psychoanalytical work with people with learning disabilities and the similar work of others.

As such, the book benefits from having chapters written by authors from a wide range of European cultural, professional, theoretical and service system backgrounds. Several authors pay tribute to the pioneering clinical, theoretical and political work of the French psychoanalyst Maud Mannoni who died in March 1998. Chapter authors also draw on the work of Bettelheim, Bion, Freud, Gaedt, Goethe, Klein, Lacan, Öe, Sinason, Tustin and Winnicott.

Given the authors' diverse backgrounds, languages and psychoanalytical perspectives, chapters vary in their organisation, accessibility and overall quality. Though the book covers individual psychoanalytical therapy and family issues extensively, and to some extent systemic and institutional psychodynamic issues, I was disappointed by the relatively limited consideration of group psychoanalytical work with people with learning disabilities (apart from in the final chapter by the only UK contributor, Valerie Sinason).

Key themes include needing to acknowledge and tolerate the anxieties associated with difference, disability-associated thinking and communication difficulties; appreciating transference and countertransference issues; and defence mechanisms for all people encountering disability, handicap and debility. Several chapters use rich clinical material to illustrate the key psychoanalytical issues in the lives of people with disabilities namely identity, dependency, sexuality, trauma and bereavement.

Several authors also provide theoretical and clinical evidence that people with learning disabilities have the capacity for insight and can make good use of psychoanalytical therapies, despite their primary organic disabilities and particularly given their frequent secondary psychosocial handicaps and psychic-numbing and stupefying traumatic experiences.

Some chapters explore family issues including mother-child dynamics, the effects of trauma and guilt on the siblings who are not disabled, the relationship between a sole-caring father and his disabled son, and intra-familial abuse. Other chapters draw on the fields of anthropology, politics, literature, mythology and art, particularly when considering monstrosity, sexuality, 
exclusion/integration, institutionalisation and normalisation issues.

Overall, given this book's wide-ranging European professional, service and theoretical prospectives, it should prove a useful contribution to the growing international literature on psychotherapy for people with learning disabilities. In the UK, analytical psychotherapy provision for people with learning disabilities is extremely patchy and mainly provided in specialised centres such as the Tavistock Clinic, London.

I recommend this book primarily to professionals undertaking and supervising analytically-informed psychotherapy work for people with learning disabilities. They should find that this interesting and easily readable book will broaden the theoretical perspectives underpinning their clinical psychotherapy work and lead to better psychodynamic under- standing of people with learning disabilities, their families and carers. The book would also be a useful addition to psychiatry and psychology of learning disabilities and psychotherapy departmental libraries.

Shaun Gravestock Consultant/Honorary Senior Lecturer in Psychiatry of Learning Disabilities, Oxleas NHS Trust, 183 Lodge Hill, Abbey Wood, London SE2 OAY

\section{Basic Family Therapy (4th edn)}

By Philip Barker. Oxford: Blackwell Science. 1998. 320 pp. $€ 19.99$ (pb) ISBN 0-632-04259-I

In recent years, the family therapy movement seems to have sometimes deliberately enjoyed producing obscure texts using impenetrable jargon. This book does what its title claims and is a basic, clearly written overview of the subject. The format has remained the same since the previous edition in 1992, but the text has been updated where necessary, for example in the chapter on research and the section on informed consent.

There are issues that cannot be explored in depth, and content on particular complications such as family violence and child abuse is limited. However, there is a large bibliography to allow more detailed reading.

As a text for trainees, it is helpful by being clear and is interesting enough to tempt beginners into reading further works. The book is good value for money and worth any library updating to this edition.

Rachel Leheup Consultant Child and Adolescent Psychiatrist, Thorneywood, Porchester Road, Nottingham NG3 6LF 